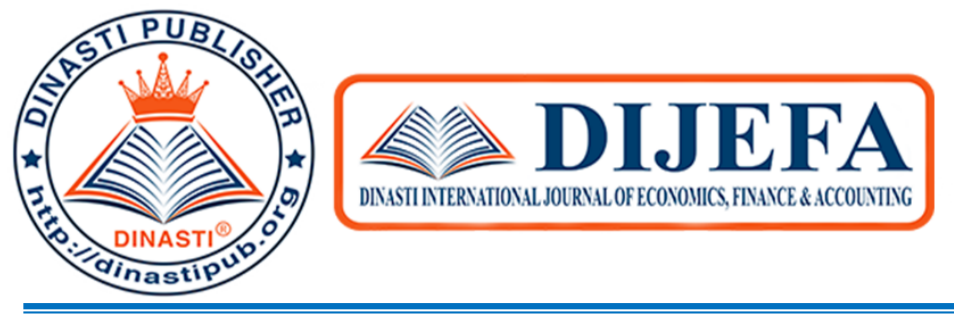

\title{
THE EFFECT OF STOCK SPLIT ANNOUNCEMENT ON THE TRADING VOLUME ACTIVITY, ABNORMAL RETURN, AND BID ASK SPREAD (STUDY ON COMPANIES LISTED ON THE IDX FOR THE PERIOD OF 2015 - 2019)
}

\section{Rimada Diamanta Putri, Pardomuan Sihombing}

Magister Manajemen Universitas Mercu Buana, Jakarta, Indonesia

\begin{tabular}{|c|l|}
\hline $\begin{array}{c}\text { ARTICLE INFORMATION } \\
\text { Received: 12 August 2020 } \\
\text { Revised: 26 August 2020 } \\
\text { Issued: 24 September 2020 }\end{array}$ & $\begin{array}{l}\text { Abstract: This research is motivated by companies that carry out } \\
\text { corporate actions in the form of stock splits. The corporate action } \\
\text { aims to increase the liquidity of the outstanding shares and to give } \\
\text { a positive signal to the company's performance in the future. To } \\
\text { find out whether this signal is true or not, it is necessary to test } \\
\text { market efficiency which proves that the stock split has an effect } \\
\text { on changes in stock trading volume, abnormal returns and the bid } \\
\text { ask spread. This type of research is the event study research with } \\
\text { a quantitative approach. A sample of } 66 \text { companies using } \\
\text { purposive sampling technique. The company under study is a } \\
\text { diamanta.putri92@gmail.com } \\
\text { company that carried out a stock split and is listed on the } \\
\text { Indonesia Stock Exchange for the period 2015 - 2019. The type } \\
\text { of data used in this study is secondary data in the form of daily } \\
\text { data on sales of shares, number of shares outstanding, stock price } \\
\text { (close price), price index. joint stock, stock offer and bid during } \\
\text { the period 2015 - 2019. The results of the research through the } \\
\text { Wilcoxon Signed Ranks Test with the results (1) There is no } \\
\text { significant difference between stock trading volume before and } \\
\text { after the stock split; (2) There is a significant difference between } \\
\text { abnormal returns before and after the stock split; (3) There is no } \\
\text { significant difference between the bid ask spread before and after } \\
\text { the stock split. } \\
\text { Keywords: Trading Volume Activity, Abnormal Return, Bid } \\
\text { Ask Spread, Stock Split. }\end{array}$ \\
DOI:10.38035/DIJEFA
\end{tabular}

\section{INTRODUCTION}

One of the strategies that companies can use to increase the liquidity of their shares is to take corporate action. Corporate action is an activity that can affect both the number of shares outstanding and the price moving in the market. Generally corporate actions must be approved 
through the General Meeting of Shareholders (GMS) and the Extraordinary General Meeting of Shareholders (EGMS).

One of the common corporate actions taken slowly is a stock split. Stock Split is the splitting of one share into $n$ shares (Jogiyanto, 2013) where one of the main objectives is to increase the liquidity of a company's stock trading. By carrying out a stock split, of course, the price of shares in circulation will be more affordable to many investors, this will certainly increase liquidity and stock returns will automatically increase.

Usually the cause of a stock split is because the stock price is too high, which will reduce the ability of investors to buy these shares. Through a stock split, stock prices will be more affordable and the trading volume of these shares will also increase. The trading volume of shares or trading volume activity is a comparison between the number of shares traded at a certain time and the number of company shares outstanding at a certain period (Jogiyanto, 2014).

Investors are interested in investing in stocks where everything is known for sure, which is shown by a positive abnormal return around the split announcement. Abnormal return is the difference between the actual return (actual return) with the expected return (expected return) (Jogiyanto, 2013).

One of the other parameters in determining the level of liquidity is the Bid Ask Spread. Bid Ask Spread is the difference between the highest price requested to buy and the lowest price offered to sell. The lower the percentage of the spread, the more liquid the shares will be, meaning that the chance of buying and selling shares will be greater if the percentage of spread is low, on the other hand, if the percentage of spreads is high, the chance of buying and selling shares will decrease which results in the share liquidity level decreasing.

During the last 1 year, namely 2019, there were 12 emiten that took corporate actions in the form of a stock split. The following is the data on the average Stock Trading Volume, Abnormal Return and Bid Ask Spread for the 5 days before and 5 days after the stock split was announced.

Table 1 The Average Trading Volume for the 5 days before and 5 days after the Stock Split

\begin{tabular}{lcc}
\hline Emiten & $\begin{array}{c}\text { TVA } \\
\text { Before }\end{array}$ & $\begin{array}{c}\text { TVA } \\
\text { After }\end{array}$ \\
\hline TBIG & 0.001837 & 0.001789 \\
ANDI & 0.006788 & 0.002902 \\
MDKA & 0.003312 & 0.002798 \\
JSKY & 0.01057 & 0.011414 \\
TMAS & 0.002829 & 0.001833 \\
PTSN & 0.001478 & 0.00342 \\
TAMU & 0.001499 & 0.001812 \\
CARS & 0.000936 & 0.000446 \\
TOBA & 0.000005 & 0.000009 \\
LPIN & 0.000147 & 0.00021 \\
ZINC & 0.005929 & 0.005544 \\
MARK & 0.000236 & 0.002058 \\
\hline Average & $\mathbf{0 . 0 0 2 9 6 4}$ & $\mathbf{0 . 0 0 2 8 5 3}$ \\
\hline
\end{tabular}


Source : The Indonesian Capital Market Institute (TICMI)

It can be seen in the table above that the average Stock Trading Volume after the stock split actually decreased, even though it was not significant.

Table 2 Average Abnormal Return for 5 days before and 5 days after Stock Split

\begin{tabular}{lcc}
\hline Emiten & $\begin{array}{c}\text { AR } \\
\text { Before }\end{array}$ & $\begin{array}{c}\text { AR } \\
\text { After }\end{array}$ \\
\hline TBIG & -0.00794 & -0.01684 \\
ANDI & 0.025844 & -0.01225 \\
MDKA & -0.00833 & -0.0042 \\
JSKY & 0.004185 & -0.01743 \\
TMAS & 0.052383 & -0.00494 \\
PTSN & 0.030363 & -0.01087 \\
TAMU & 0.009063 & 0.034586 \\
CARS & 0.020963 & 0.002856 \\
TOBA & 0.001311 & 0.025206 \\
LPIN & 0.009563 & 0.005439 \\
ZINC & 0.015045 & -0.00781 \\
MARK & 0.004983 & 0.040438 \\
\hline Average & $\mathbf{0 . 0 1 3 1 1 9}$ & $\mathbf{0 . 0 0 2 8 5}$ \\
\hline
\end{tabular}

Source : The Indonesian Capital Market Institute (TICMI)

Seen in the table and graph above that the average abnormal return after the stock split actually decreased significantly.

Table 3 Average Bid Ask Spread for 5 days before and 5 days after Stock Split

\begin{tabular}{lcc}
\hline Emiten & $\begin{array}{c}\text { BAS } \\
\text { Before }\end{array}$ & $\begin{array}{c}\text { BAS } \\
\text { After }\end{array}$ \\
\hline TBIG & 0.005357 & 0.008349 \\
ANDI & 0.010166 & 0.004369 \\
MDKA & 0.003927 & 0.004044 \\
JSKY & 0.009433 & 0.010565 \\
TMAS & 0.007833 & 0.005973 \\
PTSN & 0.005055 & 0.008734 \\
TAMU & 0.004007 & 0.008586 \\
CARS & 0.011737 & 0.021579 \\
TOBA & 0.066147 & 0.050972 \\
LPIN & 0.095742 & 0.007231 \\
ZINC & 0.003698 & 0.009032 \\
MARK & 0.008489 & 0.007183 \\
\hline Average & $\mathbf{0 . 0 1 9 2 9 9}$ & $\mathbf{0 . 0 1 2 2 1 8}$ \\
\hline
\end{tabular}


Source : The Indonesian Capital Market Institute (TICMI)

It can be seen in the table above that the average bid ask spread after the stock split has decreased.

If there is no economic benefit, the question is why the company did a stock split. The share split event is still a phenomenon that is still interesting to discuss. This is indicated by the inconsistency between theory and practice. Theoretically, stock splits only add to the number of shares outstanding and do not directly affect the company's cash flow, but empirical evidence shows that the market reacts to announcements of stock splits.

\section{LITERATURE REVIEW}

\section{Efficient Market Hypothesis}

According to Sihombing (2018) financial markets have an important role in bringing together those who provide and need funds. Apart from creating a flow of funds, financial markets also play an important role in encouraging capital formation and creating fair market prices. Therefore, the financial market system is encouraged to be efficient (efficient market). Market efficiency into three types, namely:

1. Weak form of market efficiency (leak for the efficient Market Hypothesis).

2. Efficiency of the half strong form (semistrong for of the efficient hypothesis).

3. Efficient Market Strong Form (Strong Form).

\section{Signaling Theory}

Signal theory (signaling theory) was first introduced by Spence in his research entitled Job Market Signaling. Spence (1973) argues that the sender (owner of information) seeks to provide relevant pieces of information that can be utilized by the recipient, the recipient will then adjust his behavior according to his understanding of the signal.

\section{Trading Range Theory}

According to the trading range theory, stock splitting is used as a tool to reset stock prices to the desired price range so that it is increasingly possible for investors to buy in large quantities. If the price in the pre-split is high, the stock split will further strengthen the truth of the motive.

\section{Corporate Action}

According to Darmaji and Fakhrudin (2006), corporate action is an activity of an issuer that affects the number of shares outstanding as well as the price of shares in the market. Corporate Action is news that generally attracts the attention of parties related to the capital market, especially shareholders.

\section{Stock Split}

Stock Split is a company policy to split the stock because it is considered too high. The company's decision to do a stock split illustrates the condition of the company that has good financial performance. Investors and observers generally have a positive view of each company that conducts a stock split, especially a short-term view. 


\section{Trading Volume Activity}

Trading Volume is an instrument that can be used to see the capital market's reaction to information through the parameter of the volume of shares traded on the market. Stock trading volume is the ratio between the number of shares traded at a certain time to the number of shares outstanding at a certain time.

Stock Trading Volume can be measured by the amount of Trading Volume Activity (TVA). To calculate Trading Volume Activity, you can use the following formula (Copeland, 1979):

$$
T V A=\frac{\text { company } \mathrm{i} \text { trading shares at time } \mathrm{t}}{\text { company i shares that were outstanding at time } \mathrm{t}}
$$

The average TVA before the stock split announcement uses the following formula:

$$
\text { TVA before }=\underbrace{-5}_{t=-1} \frac{T V A_{T}}{5}
$$

Explanation:

TVAi,t : Trading volume from company

$\mathrm{i}$ at time $\mathrm{t}$

TVA : Average TVA across samples

on day $\mathrm{t}$

\section{Abnormal Return}

Abnormal return or excess return is the excess of returns that actually occur against normal returns, where normal returns are expected returns (returns expected by investors), thus abnormal returns (abnormal returns) are the difference between actual returns that occur with expected returns (Jogiyanto, 2013).

The formula used is in accordance with the market adjusted model as follows:

$$
\text { ARit }=\text { Rit }-E R
$$

Explanation :

ARit : stock i abnormal return on the day

$\mathrm{t}-\mathrm{t}$

Rit : actual stock return $\mathrm{i}$ on day $\mathrm{t}$

$E R$ : expected market return on day $\mathrm{t}$

$$
R i t=\left[\frac{P i_{t}-P i_{t-1}}{P i_{t-1}}\right]
$$

Explanation : 
Rit : Actual Return of shares i on time $\mathrm{t}$

Pit : Share price $\mathrm{i}$ at time $\mathrm{t}$

Pit-1 : Share price i at time t-1

$$
E R=\left[\frac{I H S G_{t}-I H S G_{t-1}}{I H S G_{t-1}}\right]
$$

Explanation:

ER : expected return

IHSGt : Composite Stock Price Index on day $\mathrm{t}$

IHSGt-1: Composite Stock Price Index on day $\mathrm{t}-1$

\section{Bid Ask Spread}

The Bid Ask Spread used in this study is the Bid Ask Spread which is obtained on the fifth day after the stock split announcement is announced, on the grounds that liquidity changes that occur as a result of the decline in share prices should occur on and after the stock split announcement date. Bid Ask Spread measurement can be calculated using the following formula :

$$
\% \text { Spread } i, t=\frac{\text { ASK }_{t}-\text { BID }_{t}}{\left(\text { ASK }_{t}+\text { BID }_{t}\right) / 2}
$$

Explanation :

$\%$ Spread i, t : Percentage of stock spread i on t-day

BID $t \quad$ : The price of buying shares on the day $-\mathrm{t}$

ASK $t \quad$ : The selling price of the shares on the day

\section{RESEARCH METHOD}

\section{Types of Research}

This type of research is the event study research. The event window in this study is 5 trading days before the stock split announcement to 5 days after the stock split announcement. The share split announcement date is used as $\mathrm{t}=0$.

\section{Population and Samples}

The population that is the object of this research is companies listed on the Indonesia Stock Exchange (BEI) for the period 2015 - 2019. Then the sampling technique used is purposive sampling. Purposive sampling is the selection of samples using certain criteria. Obtained a sample of 66 companies. 


\section{Data Analysis Methods}

In this study, using parametric statistical analysis of difference test. Different tests are performed to prove whether there is a significant impact of the stock split on stock liquidity before and after the stock split. This test was conducted with the Paired Sample t-Test, but if the data were not normally distributed, the test used was the nonparametric Wilcoxon Signed Ranks Test. To test the normality of the data, the Kolmogorov - Smirnov test will be used, namely by comparing the asymtotic significance (2-tailed) (Ghozali, 2013).

\section{RESULTS AND DISCUSSION}

\section{Statistic Description Analysis}

Statistic description analysis for the variable stock trading volume, abnormal return and bid ask spread, in the period before and after the stock split announcement date is presented in the following table:

Table 4 : Statistics Description of Volume TradingActivity, Abnormal Return and Bid ASk Spread before the Stock Split

\begin{tabular}{lr|r|r|r|r}
\multicolumn{7}{c}{ Descriptive Statistics } \\
& N & Min & Max & Mean & $\begin{array}{c}\text { Std. } \\
\text { Deviation }\end{array}$ \\
\hline TVA & 66 &, 00 &, 01 &, 0010 &, 00191 \\
\hline AR & 66 &,- 03 &, 16 &, 0123 &, 02668 \\
\hline BAS & 66 & $-5,85$ & 2,00 &, 0226 &, 85652 \\
\hline $\begin{array}{l}\text { Valid N } \\
\text { (listwise) }\end{array}$ & 66 & & & & \\
\hline
\end{tabular}

Table 5 : Statistics Description of Volume Trading Activity, Abnormal Return and Bid Ask Spread after the Stock Split

\begin{tabular}{lr|r|r|r|r}
\multicolumn{7}{c}{ Descriptive Statistics } \\
& N & Min & Max & Mean & $\begin{array}{c}\text { Std. } \\
\text { Deviation }\end{array}$ \\
\hline TVA & 66 &, 00 &, 01 &, 0011 &, 00195 \\
\hline AR & 66 &,- 05 &, 10 &, 0022 &, 02516 \\
\hline BAS & 66 &, 00 & 2,00 &, 1842 &, 48753 \\
\hline $\begin{array}{l}\text { Valid N } \\
\text { (listwise) }\end{array}$ & 66 & & & & \\
\hline
\end{tabular}

From the table above it can be seen that:

1. In the trading volume activity variable, the lowest trading volume activity value in the period before the stock split was 0.00 , and the highest was 0.01 , then the mean was 0.0010 with a 
standard deviation of 0.00191. Meanwhile, in the period after the stock split, it can be seen that the lowest trading volume activity value is 0.00 , and the highest is 0.01 , then the mean is 0.0011 with a standard deviation of 0.00195 . The average trading volume activity variable which is smaller than the standard deviation shows that there is a deviation from the average value.

2. For the abnormal return variable, the lowest abnormal return value in the period before the stock split was -0.03 , and the highest was 0.16 , then the mean was 0.0123 with a standard deviation of 0.02688. Meanwhile, in the period after the stock split, it can be seen that the lowest abnormal return value is -0.05 , and the highest is 0.10 , then the mean is 0.0022 with a standard deviation of 0.2516 . The average abnormal return variable that is smaller than the standard deviation indicates that there is a deviation from the average value.

3. In the bid ask spread variable, the lowest spread value in the period before the stock split was 5.85 , and the highest was 2.00 , then the mean was -0.0226 with a standard deviation of 0.85652 . Meanwhile, in the period after the stock split, it can be seen that the lowest spread value is 0.00 , and the highest is 2.00 , then the mean is 0.1842 with a standard deviation of 0.48753 . The average bid ask spread variable which is smaller than the standard deviation indicates that there is a deviation from the average value.

\section{Data Normality Analysis}

The data normality test conducted was the Kolmogorov - Smirnov Test.

Table 6 : Average Normality Test Prior Trading Volume Activity and After the Stock Split

\begin{tabular}{llr|r} 
& & & \multicolumn{1}{c}{ TVA } \\
& & TVA Before & \multicolumn{1}{c}{ After } \\
\hline $\mathrm{N}$ & 66 & 66 \\
\hline Normal & Mean &, 0010 &, 0011 \\
\cline { 2 - 4 } $\begin{array}{l}\text { Parameters } \\
\text { a,b }\end{array}$ & Std. &, 00191 &, 00195 \\
\hline Most & Deviation & & \\
\cline { 2 - 4 } Extreme & Absolute &, 295 &, 295 \\
\cline { 2 - 4 } Differences & Positive &, 262 &, 260 \\
\cline { 2 - 4 } & Negative &,- 295 &,- 295 \\
\hline Test Statistic &, 295 &, 295 \\
\hline Asymp. Sig. (2-tailed) &, $000^{c}$ &, $000^{c}$ \\
\hline
\end{tabular}

Source : Processed data, 2020.

Based on the results of the Kolmogorov-Smirnov test as in the table above, it shows that the Share Trading Volume variable before the stock split announcement has a probability of 0.000 $<0.05$ and trading volume activity after the stock split announcement has a probability of 0.000 $<0.05$, so that the two variables not normally distributed. Because the data are not normally distributed, the hypothesis testing in this study will be carried out by a non-parametric test using the Wilcoxon Signed Ranks Test. 


\section{Table 7 : Average Normality Test Abnormal Return Before and After the Stock Split}

\begin{tabular}{|c|c|c|c|c|c|}
\hline \multirow{6}{*}{$\begin{array}{l}\text { Based on the } \\
\text { Smirnov test as in } \\
\text { the abnormal return } \\
\text { announcement has } \\
\text { and the abnormal } \\
\text { announcement has } \\
\text { so that the two }\end{array}$} & & & $\begin{array}{c}\text { AR } \\
\text { Before } \\
\end{array}$ & AR After & \multirow{9}{*}{$\begin{array}{l}\text { results of the Kolmogorov- } \\
\text { the table above, it shows that } \\
\text { variable before the stock split } \\
\text { a probability of } 0.000<0.05 \\
\text { return after the stock split } \\
\text { a probability of } 0.000<0.05 \text {, } \\
\text { variables not normally } \\
\text { Because the data are not } \\
\text { distributed, the hypothesis } \\
\text { will be carried out by a non- } \\
\text { using the Wilcoxon Signed }\end{array}$} \\
\hline & \multicolumn{2}{|l|}{$\mathrm{N}$} & 66 & 66 & \\
\hline & \multirow{2}{*}{$\begin{array}{l}\text { Normal } \\
\text { Parameters } \\
\text { b }\end{array}$} & Mean & ,0123 & ,0022 & \\
\hline & & Std. Deviation & ,02668 & ,02516 & \\
\hline & \multirow{3}{*}{$\begin{array}{l}\text { Most } \\
\text { Extreme } \\
\text { Differences }\end{array}$} & Absolute & , 188 & , 159 & \\
\hline & & Positive & , 188 & , 159 & \\
\hline normally & & Negative &,- 159 &,- 113 & \\
\hline testing in this study & \multicolumn{2}{|l|}{ Test Statistic } & , 188 & ,159 & \\
\hline parametric test & \multicolumn{2}{|c|}{ Asymp. Sig. (2-tailed) } &, $000^{\mathrm{c}}$ &, $000^{\circ}$ & \\
\hline
\end{tabular}

Table 8 : Average Normality Test Bid Ask Spread Before and After the Stock Split

\begin{tabular}{llr|r} 
& & \multicolumn{1}{c|}{$\begin{array}{c}\text { BAS } \\
\text { Before }\end{array}$} & \multicolumn{1}{c}{$\begin{array}{c}\text { BAS } \\
\text { After }\end{array}$} \\
\hline $\mathrm{N}$ & 66 & 66 \\
\hline Normal & Mean &, 0226 &, 1842 \\
\cline { 2 - 4 } $\begin{array}{l}\text { Parameters } \\
\text { a }\end{array}$ & Std. &, 85652 &, 48753 \\
\cline { 2 - 4 } Most & Deviation & & \\
\hline Extreme & Absolute &, 445 &, 436 \\
\cline { 2 - 4 } Differences & Positive &, 330 &, 436 \\
\cline { 2 - 4 } & Negative &,- 445 &,- 355 \\
\hline Test Statistic &, 445 &, 436 \\
\hline Asymp. Sig. (2-tailed) &, $000^{\circ}$ &, $000^{\circ}$ \\
\hline
\end{tabular}

Source : Processed data, 2020.

Based on the results of the Kolmogorov-Smirnov test as in the table above, it shows that the bid ask spread variable before the stock split announcement has a probability of $0,000<0.05$ and the bid ask spread after the stock split announcement has a probability of $0,000<0.05$, so that the two variables not normally distributed. Because the data are not normally distributed, the hypothesis testing in this study will be carried out by a non-parametric test using the Wilcoxon Signed Ranks Test.

\section{First Hypothesis}

The first hypothesis states that there are significant differences in trading volume in the period before and after the announcement of a stock split. Trading volume is proxied via Trading Volume Activity (TVA). 
After knowing the average TVA of all samples in the period before and after the announcement of the stock split, then the Wilcoxon Signed Ranks Test is carried out which is shown in the following table :

Table 9 : Wilcoxon Signed Ranks Test Trading Volume Activity

\begin{tabular}{lr} 
& \multicolumn{2}{c}{ TVA Before - } \\
& \multicolumn{2}{c}{ TVA After } \\
\hline$Z$ &,$- 546^{\mathrm{b}}$ \\
\hline Asymp. Sig. (2-tailed) &, 585 \\
\hline
\end{tabular}

The results of the Wilcoxon Signed Ranks Test on the variable stock trading volume, obtained a Z count of -, 546 with a probability of 0.585 . Therefore, when this variable generates a probability of $0.585>0.05$, maha $\mathrm{H} 0$ is accepted and it can be said that there is no significant difference in the volume of stock trading between before and after the company implemented the stock split policy. Thus the second hypothesis in this study is rejected.

\section{Second Hypothesis}

The second hypothesis states that there is a significant difference in abnormal returns in the period before and after the stock split. After knowing the average abnormal return (AR) in the period before and after the announcement of the stock split, then the Wilcoxon Signed Ranks Test is carried out which is shown in the following table:

\begin{tabular}{|c|c|c|}
\hline \multirow[t]{5}{*}{ Table 10} & \multicolumn{2}{|c|}{ : Wilcoxon Signed Ranks Test Abnormal Return } \\
\hline & \multicolumn{2}{|c|}{ AR Before - AR } \\
\hline & \multicolumn{2}{|c|}{ After } \\
\hline & Z & $-2,782^{b}$ \\
\hline & Asymp. Sig. (2-tailed) & ,005 \\
\hline
\end{tabular}

The test results on the abnormal return, using the Wilcoxon Signed Ranks Test hypothesis test, obtained a $\mathrm{Z}$ count of -2.782 with a probability of 0.005 . Therefore, when the variable produces a probability of $0.005<0.05, \mathrm{H} 0$ is also rejected and it can be concluded that there is a significant difference in abnormal returns between before and after the company applies a stock split policy. Thus the second hypothesis in this study was accepted.

\section{Third Hypothesis}

The third hypothesis in this study states that there is a significant difference in the bid ask spread in the period before and after the stock split announcement. After knowing the average bid ask spread in the period before and after the stock split, then the Wilcoxon Signed Ranks Test is carried out which is shown in the following table: 
Table 11: Wilcoxon Signed Ranks Test Bid Ask Spread

\begin{tabular}{lr} 
& \multicolumn{2}{c}{$\begin{array}{c}\text { BAS Before - } \\
\text { BAS After }\end{array}$} \\
\hline$Z$ &,$- 821^{\mathrm{b}}$ \\
\hline Asymp. Sig. (2-tailed) &, 412 \\
\hline
\end{tabular}

The results of the Wilcoxon Signed Ranks Test on the bid ask spread variable, obtained a Z count of -0.821 with a probability of 0.412 . Therefore, when this variable generates a probability of $0.412>0.05$, then $\mathrm{H} 0$ is accepted and it can be said that there is no significant difference between the bid ask spread before and after the company implements the stock split policy. Thus the first hypothesis in the study is rejected.

\section{Trading Volume Activity}

From the results of testing the first hypothesis proves that there is no statistically significant difference between the TVA before and after the stock split, so the hypothesis which states that there is a significant difference in TVA in the period before and after the stock split is not proven. Based on the average value, the TVA before the announcement of the stock split was 0.0010 and after the announcement of the stock split was 0.0011 .

From a theoretical point of view, namely in terms of trading range theory, which states that by doing stock splits, stocks will become more liquid so that more investors will be able to transact or there will be an increase in the volume of stock trading proxied through TVA is not proven. The results of the research actually proved that the stock split did not result in a significant difference in TVA in the period before and after the announcement of the stock split. The absence of a significant market reaction after the announcement of the stock split reflects that investors in Indonesia have not properly anticipated the information received through the capital market or investors think that the stock split event is not a good policy for the future.

The results of this study support previous research conducted by Rohmah (2018) which states that stock split has no effect on stock trading volume both before and after stock splits, in line with research conducted by Sanusi (2018) which states that there is no significant difference from Stock liquidity as measured by the volume of stock trading before and after the implementation of the stock split policy.

However, it does not support the research conducted by Safira (2016), which in his research states that there are significant differences in trading volume activity in the period before and after the stock split. The results of this study are also not in line with the results of research from 
Merthadiyanti (2019) which states that stock splits have an effect on trading volume activity both before and after the stock split.

\section{Abnormal Return}

From testing the second hypothesis, statistically found a significant difference between abnormal returns before and after events, so the hypothesis which states that there are significant abnormal return differences in the period before and after the stock split is accepted.

Based on the average abnormal return before the announcement of the stock split was 0.0123 and the abnormal return after the stock split announcement was 0.0022 . These results prove that there is a significant difference in abnormal returns in the period before and after the stock split.

From a theoretical point of view, namely in terms of signaling theory, which states that signaling theory is related to the presence of information asymmetry between managers and investors, where managers can use stock splitting to provide positive signals to the market about their future expectations. The stock-splitting activity carried out by the company will be interpreted by investors as a signal that the manager has beneficial information, which is indicated by a significant abnormal return around the stock split announcement.

The results of this study support the results of research conducted by Puspita (2019) which found that the stock split has an effect on abnormal returns both before and after the announcement of the stock split. It is also in line with research conducted by Rohmah (2019) which states that there are differences in abnormal returns around the announcement of the stock split.

However, the results of this study are not in line with research conducted by Yustisia (2018) which found that there was no change in abnormal returns during the stock split announcement period. It is also not in line with research conducted by Adisetiawan (2018) which states that the stock split action has no effect on abnormal returns.

\section{Bid Ask Spread}

From the results of testing the third hypothesis, it is statistically concluded that there is no significant difference in the bid ask spread between the periods before and after the stock split. The percentage spread after the stock split is greater than before the stock split. Based on Trading range theory, stock split is expected to increase stock liquidity, but due to the stock split policy, brokerage transaction costs incurred in proportion increase so that the Bid Ask Spread will also increase.

The bid ask spread is a function of the three cost components derived from share ownership, information asymmetry, and order processing. The results of this study indicate that stock splits do not increase investor attractiveness so that inadequate stock trading is more active. This is also made possible by the uneven distribution of information among market players so that the percentage of the bid ask spread does not decrease or even widen. Some companies may be in a condition where fundamentals are less trusted and try to give invalid signals through stock splits, so that investors will catch the information as bad news and react badly to it.

The results of this study support the results of a study conducted by Yustisia (2018) who obtained the same results ie there was no difference in the bid ask spread in the period before and after the stock split. The same result was also obtained by Utami (2017) who stated that the announcement of the stock split had no effect on the bid ask spread around the announcement. 
However, the results of this study are not in line with the research conducted by Adisetiawan (2018) who found that there was a change in the bid ask spread during the announcement of the stock split. This research is not in line with the research conducted by Widasari (2018) which states that the stock split action affects the bid ask spread.

\section{CONCLUSIONS AND RECOMMENDATIONS}

\section{Conclusions}

1. Based on statistical tests on the average daily stock trading volume before and after the stock split, it is found that there is no significant difference in the average share trading volume in the period before and after the stock split.

2. Based on statistical tests on daily abnormal returns before and after the stock split event, it was found that there was a significant difference between abnormal returns before and after the stock split.

3. Based on the statistical test of the daily Bid ask spread before and after the stock split, it was found that there was no significant difference in the period before and after the stock split.

\section{Recommendations}

1. For further researchers

a. Further research needs to add other variables that may be influenced by the stock split and use a wider variable.

b. Doing continuous research, it aims to see whether the results of this study are still in line or get different results from before.

c. In future recearsh, it is recommended to take more samples, this is aimed at better data accuracy in future studies.

d. Extend the observation period used.

2. For Companies

The companies used as samples are still limited to companies listing on the Indonesia Stock Exchange for the period 2015-2019, so further research is needed using different research samples within a longer observation time so that it is expected that the results obtained can be generalized.

\section{REFERENCES}

Adisetiawan, R. 2018. Does Stock Split Influluence to Liquidity and Stock Return. Jurnal Ekonomi, Vol. 8. No. 5. 682-290.

Brigham, E.F. dan Houston. 2011. Dasar-dasar Manajemen Keuangan. Edisi 11. Buku 2. Jakarta: Salemba Empat.

Copeland, T. E. 1979. Liquidity Changes Following Stock Splits. The Journal Of Finance, 34(1). Fauzi, Shochihatuz. 2016. Pengaruh Pengumuman Stock Split Terhadap Likuiditas Saham dan Return Saham. Fakultas Ilmu Administrasi Universitas Brawijaya Malang.

Ghozali, Imam. 2013. Aplikasi Analisis Multivariat dengan Program IBM SPSS. Edisi 7. Semarang: Penerbit Universitas Diponegoro. 
Hartono, Jogiyanto. 2014. Teori Portofolio dan Analisis Investasi. Edisi Kedelapan. Yogyakarta: BPFE.

Hartono, Jogiyanto. 2013. Teori Portofolio dan Analisis Investasi. Edisi Kelima. Yogyakarta: BPFE.

Merthadiyanti, Luh. 2019. Analisis Trading Volume Activity dan Bid Ask Spread Setelah Stock Split. E-jurnal Akuntansi Universitas Udayana. Vol. 27, No. 1. 311-335.

Puspita, Nindi, dkk. 2019. Analisi Pengaruh Stock Split terhadap Harga Saham, Abnormal Return dan Risiko Sistematik Saham Perusahaan. Jurnal Ekonomi, Vol. 4, No. 1.95 -110.

Rohmah, Elmy. 2018. Pengaruh Kebijakan Stock Split Terhadap Likuiditas Saham, Return Saham, dan Volatilitas Harga Saham. Fakultas Ekonomi Universitas Islam Indonesia.

Safira, Tania. 2016. Uji Komparasi Abnormal Return, Trading Volume, Trading Frequency, dan Bid Ask Spread Sebelum dan Sesudah Share Split. Fakultas Ekonomi Universitas Multimedia Nusantara.

Sanusi, Felix. 2018. Pengaruh Stock Split Terhadap Likuiditas Emiten di Bursa Efek Indonesia. Jurnal Riset Akuntansi dan Keuangan Universitas Prasetiya Mulya. Vol. 6. No. 2. 211-220.

Sihombing, Pardomuan. 2018. Corporate Financial Management. PT. Penerbit IPB Pres: Bogor.

Utami, Dianingsih, dkk. Analysis of Abnormal Return and Bid Ask Spread at the Period of Stock Split Announcement.

Journal of Economis and Finance, Vol. 8, No. 4. 83-93.

Widasari, Cahita. 2018. The effect of Stock Split Toward Actual Return, Trading Volume Activity and Bid Ask Spread. Fakultas Ekonomi Universitas Negeri Yogyakarta.

Yustisia, Natalie. 2018. The Impact of Stock Split on the Performance in Indonesian Manufacturing Company. Jurnal Ekonomi, Vol. 9, No. 1. 39-46.

The Indonesian Capital Market Institute

(TICMI)

www.idx.go.id

www.finance.yahoo.com

www.sahamok.com

www.google.com 